\title{
Quantitative determination of chemical and biochemical parameters during « soumbala » manufacturing process in two communities of Burkina Faso
}

\author{
Elie KABRÉ ${ }^{1,2^{*}}$, Moumouni BANDÉ ${ }^{1}$, Raoul KARFO ${ }^{2}$, Raoul BAZIÉ ${ }^{1}$, \\ Doulmouhaye SOULAMA ${ }^{2}$, Fulbert NIKIÉMA ${ }^{1}$ et Jean SAKANDÉ ${ }^{2}$
}

\author{
${ }^{1}$ Laboratoire National de Santé Publique 03 BP 24 Ouaga 03, Boulevard des Tensoba, Secteur 30 \\ Ouagadougou, Burkina Faso. \\ ${ }^{2}$ Laboratoire de Biochimie de l'UFR/SDS, Université Joseph KI-ZERBO, Burkina Faso. \\ *Corresponding author; E-mail : elie.kabre@gmail.com;Tel. +22670392375
}

\author{
Received: 29-08-2020 \\ Accepted: 20-12-2020 \\ Published: 31-12-2020
}

\begin{abstract}
«Soumbala » is traditionally used in Burkina Faso as a food condiment in different communities. This study was conducted to evaluate « soumbala » manufacturing process on its nutritional value in two communities. During this descriptive and analytical study, samples were taken in the «Gouin » and « Moose » communities. The results show that, the humidity rate was higher in «soumbala » and waste in the « Gouin » processus, whereas in the «Moose » one, the highest humidity rate was observed after the cooking step and in peeled boiled seeds. The ash level was higher in raw seeds and after cooking step in the «Gouin » community whereas in the «Moose » community, it was higher in raw seeds and waste. The $\mathrm{pH}$ determination showed a progressive increase in $\mathrm{pH}$ values during the «soumbala » manufacturing process in the two communities. Mineral elements assays showed a slight variation in grades along the «soumbala » manufacturing process. For biochemical analysis, lipids content increased during the « soumbala » production; protein levels increased a little at the early stages of «soumbala » manufacturing process in both communities and carbohydrates contents were higher in waste in the « Moose » community, whereas in the «Gouin » community, the highest contents were found in the raw seeds. The aflatoxins determination in «soumbala » showed levels below the detection limit of the used method. These results showed that it was imperative that approved standard protocols be adopted to maintain the nutritional quality of « soumbala » wherever it is produced.
\end{abstract}

(C) 2020 International Formulae Group. All rights reserved.

Keywords: Burkina Faso, « soumbala », biochemical parameters, aflatoxins.

\section{INTRODUCTION}

Parkia biglobosa, commonly called « néré » in Burkina Faso, is a legume of the Mimosaceae family. It is a $10 \mathrm{~m}$ to $15 \mathrm{~m}$ tall tree, with a parasol-like habit and alternate bipinnate leaves. The flowers are small, red, densely gathered in spherical capitules $4 \mathrm{~cm}$ to
$5 \mathrm{~cm}$ wide, pedunculated $10 \mathrm{~cm}$ to $30 \mathrm{~cm}$, sometimes in bunches, at the end of the branches of the tree. Fruits in pods from $25 \mathrm{~cm}$ to $30 \mathrm{~cm}$ long, $15 \mathrm{~mm}$ to $20 \mathrm{~mm}$ wide are flattened. When ripe, they are dark brown in colour and contain black seeds surrounded by 
a yellow floury pulp which fills the whole pod. Parkia biglobosa is native to the Sahelian and Sudanian zones. It is found in countries of West Africa (Benin, Burkina Faso, Chad, Côte d'Ivoire, Mali, Togo, Guinea, Guinea-Bissau, Nigeria, Gambia), Central Africa (Democratic Republic of Congo, Cameroon) and East Africa (Uganda) (Campbell-Platt, 2010; Ouoba et al., 2017). It is used for its countless medical and dietary virtues. Bark of Parkia biglobosa, rich in tannins $(8 \%-12 \%)$, is used as a decoction against violent colic accompanied by vomiting and diarrhoea (Sereme et al., 2008); and also in the treatment of bilharzia and gonorrhoea (Tokuba, 2012). The pod-shaped fruits of Parkia biglobosa are consumed for their floury and sweet pulp.

The plant also has other virtues. The pod is used in combination with an indigo dye to improve the tissues brightness, whereas the tree bark, which contains tannins, is used to dye copper red (Burlando et al., 2019). The tree is also used in beekeeping as a source of nectar for the bees and aids in the establishment of hives. The most valuable part of the tree is the reference seed. It is rich in protein, carbohydrates, lipids and is a good source of fat and calcium (Alabi et al., 2005). The unfermented raw seed of Parkia biglobosa is not edible. Fermentation improves its nutritional quality and digestibility by modifying its physical and chemical characteristics to make it a food with interesting nutritional properties (Popoola et al., 2007). Fermented seeds of Parkia biglobosa known as «soumbala » in Burkina Faso and Mali, "Soumara" in Côte d'Ivoire, "nététu" in Senegal and "dawa-dawa" or "iru" in Nigeria are traditionally used as a food condiment to flavour and enhance sauces taste in different communities.

Bacillus subtilis and Staphylococcus spp. are the bacterial species responsible for fermenting the «néré » seeds. These bacteria use enzymes to hydrolyze proteins into amino acids and ammonia (Ahouansou, 2012). This is a natural process involving contact with appropriate inocula and the high temperatures encountered in tropical countries. The « soumbala » manufacturing process is long (4-5 days) and includes three essential steps: cooking of the seeds followed by fermentation of the cotyledons and finally fermented product drying (Ahouansou, 2012, Dabiré et al., 2020).

The «soumbala » manufacturing process can affect its nutritional value. In Burkina Faso, it differs from one community to another. Therefore, this study was conducted in two communities (« Moose » and «Gouin ») to determine the impact both « soumbala » manufacturing processes on the end product nutritional quality.

\section{MATERIALS AND METHODS}

\section{Framework of the study}

The study was carried out at the National Public Health Laboratory and biochemistry laboratory of Joseph KI-ZERBO University.

\section{Type and period of study}

This was a descriptive and analytical study that took place from November 2018 to October 2019.

\section{Sampling}

In total, 32 samples were collected from each of the two communities, « Moose » and « Gouin ». The « Moose » community was chosen because it represents the majority community in Burkina Faso and the «Gouin » community was chosen to represent the communities in the Western region of Burkina Faso (Figure 1). The samples collected in the form of grains were finely ground with a mill (WERKE, Type M20). To limit the contamination risk, the mill was cleaned beforehand and the cleaning was repeated after each grinding. The powdered samples were stored in the refrigerator at $4{ }^{\circ} \mathrm{C}$. 


\section{Reagents and standards}

All the solutions were prepared with the double de-ionized water provided by the Milli Q water purification system (LAB TOWER AFT, Thermo scientific). Nitric acid 69\% and hydrochloric acid $37 \%$ (HYPERPUR, Panreact AppliChem) for mineral elements analysis were used to clean glassware, carrying out wet digestion and solutions preparation. An individual stock standard solution containing $1000 \mathrm{mg} / \mathrm{L}$ of iron, zinc, and selenium purchased from MERK (Germany) were used for the preparation of solutions in order to standardize calibration. A mixture standard of aflatoxins B1, B2, G1, and G2 in acetonitrile (Fluka, Sigma Aldrich) was used for aflatoxins quantification.

Solvents (methanol, acetonitrile) were HPLC grade and were purchased from ChromaSolv, Sigma Aldrich. The reagents including Phosphate buffered saline (Sigma Aldrich), sodium hydroxide (Panreact), sodium chloride (Sigma Aldrich) and Catalyzer Kjltab (Thomson and Capper) were used.

\section{Sample processing}

The «soumbala» was homogenized using stainless steel blender obtained from IKA (WERKE, type M20). In order to avoid the contamination risk, the mill was first cleaned after each crushing. The resulting « soumbala » powders were stored at room temperature.

All the analyses were carried out in triplicate.

General parameters determination: $\mathrm{pH}$, humidity and ash content

\section{The $\mathrm{pH}$ determination}

Five (5) grammes of sample were dissolved in $50 \mathrm{~mL}$ of distilled water. The obtained solution was filtered out with Whatman paper. The solution $\mathrm{pH}$ was measured using a $\mathrm{pH}$ metre WTW $\mathrm{pH} 330$ model.

\section{The water contents determination}

The samples were submitted to forced air oven drying according to AOAC 950.46 method (1997) using a forced-air oven MEMMERT (Germany). Briefly, $5 \mathrm{~g}$ of sample were weighted in the aluminium dishes and placed in the oven maintained at $103^{\circ} \mathrm{C}$ as long as a constant weight is obtained after cooling in the desiccator. The water content was determined by gravimetry.

\section{The ash content determination}

The ash content was determined according to the AOAC 920.153 method (1997). It consists in incinerating $5 \mathrm{~g}$ of sample in the muffle furnace at a temperature of 550 ${ }^{\circ} \mathrm{C}$ for thirteen hours. The ash content was determined by gravimetry.

\section{Procedures for biochemical parameters determination}

\section{The total protein contents determination}

The « soumbala » total protein contents, were determined using the KJELDAHL AOAC 979.09 method (1999). This method consists in mineralizing the organic nitrogen into ammonium by mixing $0.2 \mathrm{~g}$ of « soumbala » powder with 1 digestion tablet (consisting of $3.5 \mathrm{~g}$ of potassium sulphate, $4 \mathrm{~g}$ of copper sulphate) and $10 \mathrm{~mL}$ of sulphuric acid. The total protein content was determined by acidimetry.

The protein fraction contents determination (Albumins, Globulins, Prolamins, and Glutellins)

\section{The protein fractions extraction}

The protein fractions extraction from the different samples was carried out using the technique of Ragab et al. (2004). Briefly, « soumbala » flour $(3.5 \mathrm{~g})$ was extracted twice with $50 \mathrm{ml}$ distilled water for $30 \mathrm{~min}$ at room temperature. The extract was centrifuged at $3000 \mathrm{~g}$ for $30 \mathrm{~min}$ and the supernatant was used for a water-soluble protein determination (albumin) whose residue was then extracted 
successively in a similar manner with $1.0 \mathrm{M}$ $\mathrm{NaCl}, 70 \%$ ethanol. The supernatant of each extract was collected separately and used to estimate the salt- (globulin), alcohol(prolamin) or alkali- (glutelin) soluble fractions.

\section{The protein fractions determination}

The protein fractions contents in each sample were estimated by using Bradford's method (Bradford, 1976). This method is based on the interaction between proteins and a dye Coomassie blue. This dye binds to proteins and forms a complex with a maximum absorbance wavelength between $465 \mathrm{~nm}$ and $595 \mathrm{~nm}$. The amount of Coomassie blue that binds to proteins is proportional to their concentration in the solution. Specifically, $10 \mu 1$ of protein solution was added to $200 \mu 1$ of Bradford's reagent (bioquant kit, merck). The obtained mixture was incubated for $15 \mathrm{~min}$ and then the colour was read at $595 \mathrm{~nm}$ wavelength by using a microplate Spectrophotometer purshaged from Bioteck Epoch (USA).

\section{The total lipids Determination}

The total lipids amount was obtained by Soxhlet extraction according to the AOAC 985.15 method (1990). Briefly, this method is based on the extraction of total lipids from $5 \mathrm{~g}$ of «soumbala» flour by using $250 \mathrm{~mL}$ of petroleum ether as an extraction solvent and the Soxhlet apparatus. After extraction, the solvent was separated from lipids by reduced pressure evaporation with a rotavapor. The total lipids content is obtained by gravimetry.

\section{The carbohydrates contents Determination}

The carbohydrates contents were determined by the differential method described by Musaiger et al. (1998). This method consists of deducting the carbohydrate content from the water, fat, protein and ash contents using the following formula:

$\mathrm{C}(\%)=100-(\mathrm{H}+\mathrm{MG}+\mathrm{Pr}+\mathrm{Cn})$

$\mathrm{C}$ : Carbohydrate (\%) ; $\mathrm{H}$ : Moisture content $(\%)$; MG : Fat content (\%) ; Pr : Protein content (\%); $\mathrm{Cn}$ : Ash content (\%).
The mineral elements determination (Iron, Zinc and Selenium)

Samples were digested by the method described by Demirel et al. (2008). This method consists of mixing $0.5 \mathrm{~g}$ of samples in a mixture of $10 \mathrm{ml}$ of nitric and hydrochloric acid solutions $(3 / 1)(\mathrm{v} / \mathrm{v})$. The obtained mixture is heated up to $150{ }^{\circ} \mathrm{C}$ and then filtered with wattman paper. The final volume is made up to $20 \mathrm{ml}$ with deionized water. These solutions were used to determine mineral elements (iron, zinc, and selenium) on a VARIAN AA 240 FS atomic absorption spectrometer (Australia).

\section{The total aflatoxins determination}

To extract aflatoxins, $5 \mathrm{~g}$ of « soumbala» flour was added to $25 \mathrm{~mL}$ of a mixture of methanol and distilled water (70/30 v/v). B1, B2, G1, G2 aflatoxins were purified by passing extraction solution through an immunoaffinity column. The column contains specific antibodies attached to a solid support. As the sample passes through the column, the antibodies selectively bind to the different aflatoxins and form an anti-body-antigen complex. All other components of the sample matrix are removed from the column by water. B1, B2, G1, G2 aflatoxins were then eluted from the column. The eluate was analyzed by using an UHPLC system Diomex Ultimate 3000 purchased from TERMO SCIENTIFIC with a fluorescence detector associated with a post-column derivation.

\section{Statistical analysis}

The XLSTAT statistical software was used for survey data processing. To compare data on «soumbala » quality from different regions, the one-way ANOVA statistical test was used at a significant level of 0.05 . The normality of the data was verified by the shapiro test. For the data that were not normal, a square root transformation was performed to match the anova application criteria. 


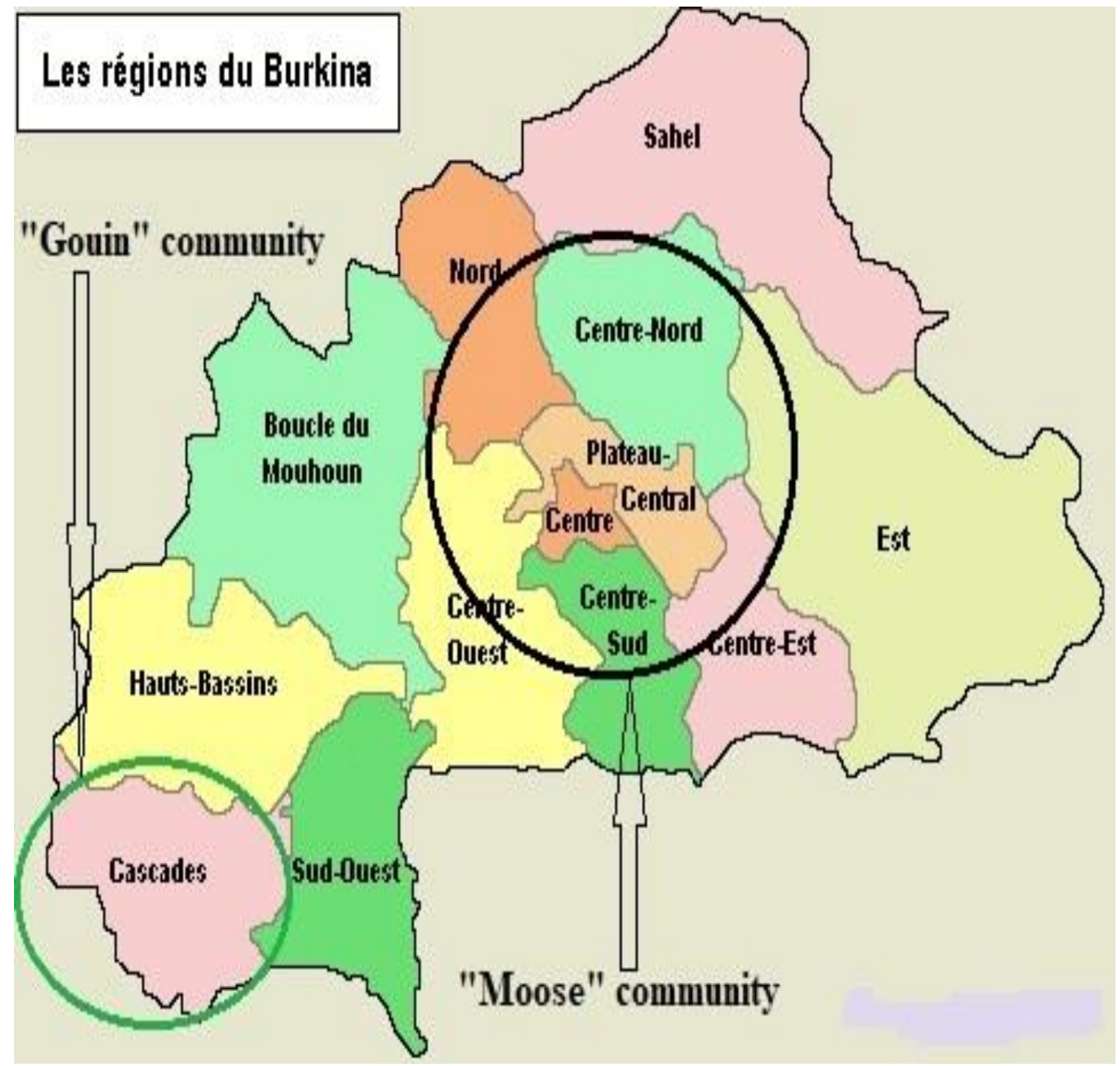

Figure 1: location of the two communities («Moose » and «Gouin ») that were selected for the study on the map of Burkina Faso.

\section{RESULTS}

\section{The Production Diagrams}

Figures 2 and 3 show the process for making «soumbala » in the «« Gouin » » and « Moose » communities respectively. The diagrams of « soumbala » production in the « Gouin » and « Moose » communities show three fundamental differences: the first difference concerned the first raw «néré » seeds treatment. In the « Gouin » community, raw « néré » seeds were directly boiled over a high heat for sixteen hours whereas in the " Moose » community, they first underwent a wetting stage for twelve hours before being boiled. The second difference related to the boiled hulled seeds treatment. While in the « Gouin », corn flour, salt, chilli pepper and two pieces of coal were added to the boiled hulled 
seeds, in the "Moose », only three pieces of coal were added. The third difference was related to the duration of the cooking and fermentation stages. In the "Gouin", the cooking and fermentation took place in 16 hours and 02 days respectively, while in the "Moose", they took place in 12 hours and 03 days.

\section{Humidity, ash and pH measurement The Humidity rate}

Figure 4 shows the " néré » seeds humidity rate during the «soumbala » manufacturing process. The humidity rate determination in the different samples revealed that in «Gouin » community, the humidity rate was higher in « soumbala » and waste while in « Moose » community, it was highest after the second cooking step and in peeled boiled seeds. A comparison of hmudity rates showed statistically significant difference between samples from the two communities $(F=4.69$, $p=0.0029 \leq 0.05$ ). A comparison of data from each of the «soumbala » production stages showed that statistically significant differences were observed at the "after cooking" and "boiled peeled seeds" stages $(\mathrm{F}=4.02, \mathrm{p}=$ $0.0062 \leq 0.05$ for the "after cooking" stage and $\mathrm{F}=4.43, \mathrm{p}=0.0021 \leq 0.05$ for for the "boiled peeled seeds" stage).

\section{The ash rate determination}

The results of the ash rate determination are summarized in Table 1. The results analysis shows that the ash rate was more important in the raw seeds and after the cooking step in the « Gouin » community whereas in the « Moose » community, it was more important in the raw seeds and waste. The soumbala ash contents were different in the two communities and this difference was statistically significant $(\mathrm{F}=$ $2.88 ; \mathrm{p}=0.0012 \leq 0.05)$. A comparison of the data from all «soumbala» stages of manufacturing showed that for the ash contents, statistically significant differences were observed at all levels $(\mathrm{F}=2.96 ; \mathrm{p}=$ $0.0064 \leq 0.05$ for raw seeds; $F=3.37 ; \mathrm{p}=$ $0.0018 \leq 0.05$ after cooking; $\mathrm{F}=3.21 ; \mathrm{p}=$ $0.0027 \leq 0.05$ at the peeled seed stage; $\mathrm{F}=$ 3.04; $\mathrm{p}=0.0032 \leq 0.05$ at the boiled peeled seed stage; $F=2.89 ; \mathrm{p}=0.0092 \leq 0.05$ at the « soumbala » stage).

\section{The $\mathrm{pH}$ determination}

Table 2 shows the results of $\mathrm{pH}$ measurements during the manufacturing process of «soumbala ». The $\mathrm{pH}$ determination showed a gradual increase in $\mathrm{pH}$ values during the « soumbala » manufacturing process in both the «Gouin » and « Moose » communities. In « Gouin » community, the $\mathrm{pH}$ ranged from 4.63 in the raw seeds to 6.03 in the end product («soumbala ») while in « Moose » community, the values ranged from 4.77 in the raw seeds to 6.53 in « soumbala ». But diffrences between $\mathrm{pH}$ values in the two communities were not statistically significant $(\mathrm{F}=2.22, \mathrm{p}=0.12 \geq 0.05)$.

\section{The mineral parameters}

Three mineral elements were mainly dosed: iron, zinc, selenium. The results obtained are recorded in Table 3. Mineral element assays showed a slight variation in grades along the «soumbala » manufacturing process in the two communities. For selenium, there were even constant grades at all manufacturing process stages. The one-way ANOVA statistical test revealed no statistically significant difference between the samples mineral element contents from the two communities $(\mathrm{F}=1.14, \mathrm{p}=0.53 \geq 0.05$ for iron; $\mathrm{F}=1.38 ; \mathrm{p}=0.24 \geq 0.05$ for zinc and $\mathrm{F}=1.57$; $\mathrm{p}=0.17 \geq 0.05$ for selenium). 


\section{Biochemical parameters The lipids contents}

The results of the lipid levels analysis in samples taken at different stages of the « soumbala » production in the « Gouin » and « Moose » communities are presented in Figure 5. The lipids analysis results showed an evolution of the levels during the « soumbala » manufacturing process. In « Gouin » community, the levels went from $11.69 \%$ in the raw seeds to $29.55 \%$ in « soumbala », while in « Moose » community, the levels varied from $14.33 \%$ to $37.42 \%$ in the raw seeds and the finished product (« soumbala ») respectively. Lipid levels in samples taken from the «Gouin » community differed significantly from those in samples taken from the « Moose » community $(\mathrm{F}=3.24 ; \mathrm{p}=0.0273 \leq 0.05)$. A comparison of data from each of the stages of «soumbala » production showed that statistically significant differences were observed at the "after cooking" and "boiled peeled seeds" stages $(\mathrm{F}=3.96, \mathrm{p}=0.0082 \leq$ 0.05 for the "after cooking" stage and $\mathrm{F}=3.43$, $\mathrm{p}=0.0128 \leq 0.05$ for for the "boiled peeled seeds" stage).

\section{The proteins content}

The protein assay results during the « soumbala » manufacturing process are summarized in Figure 6. Protein levels varied little during the early stages of « soumbala » production in the two communities, «Gouin » and « Moose ». Indeed, they went from 27.38\% in the raw seeds to $33.07 \%$ after the cooking step in «Gouin » and «Moose » communities, they varied from $29.71 \%$ in the raw seeds to $31.64 \%$ after the cooking. However, there was an increase in protein content in peeled seeds ( $45.40 \%$ in « Gouin » community and $47.55 \%$ in « Moose » community. From the peeled seed stage, there was still a small variation in protein content in the following « soumbala » manufacturing process stages: $49.14 \%$ and 47 . $96 \%$ in the peeled and boiled seed stage and $45.95 \%$ and $46.50 \%$ in the end product in «Gouin » and « Moose » communities respectively. No statistically significant difference was observed between the protein contents of the samples from the two communities «Gouin » and « Moose » $(\mathrm{F}=$ $0.61, \mathrm{p}=0.81 \geq 0.05$ ).

\section{The protein fractions contents}

The protein fractions analysis results are shown in Table 4. The protein fractions contents varied according to the stage of manufacture of «soumbala ». Among the four proteins of the protein fractions analyzed, glutelins were found at higher levels at all stages of the «soumbala » production in the two communities, « Gouin » and « Moose ». But diffrences between protein fractions contents in the two communities were not statistically significant $(\mathrm{F}=1.22, \mathrm{p}=0.37 \geq$ 0.05).

\section{The carbohydrates content}

The carbohydrates contents are presented in Table 5. The carbohydrates contents were higher in waste $(76.86 \%)$ in the « Moose » community while in the «Gouin » community, the highest content was found in raw seeds (45.34\%). A comparison of « soumbala » carbohydrates contents in both communities showed no statistically significant difference $(\mathrm{F}=0.49, \mathrm{p}=0.29 \geq$ $0.05)$.

\section{The aflatoxin contents}

The aflatoxins determination in « soumbala » from the "Gouin » and the « Moose » communities showed levels below the detection limit of the used method $(0.08 \mathrm{ppb}$ for aflatoxins B1 and $\mathrm{G} 1$ and $0.01 \mathrm{ppb}$ for aflatoxins B2 and G2). 


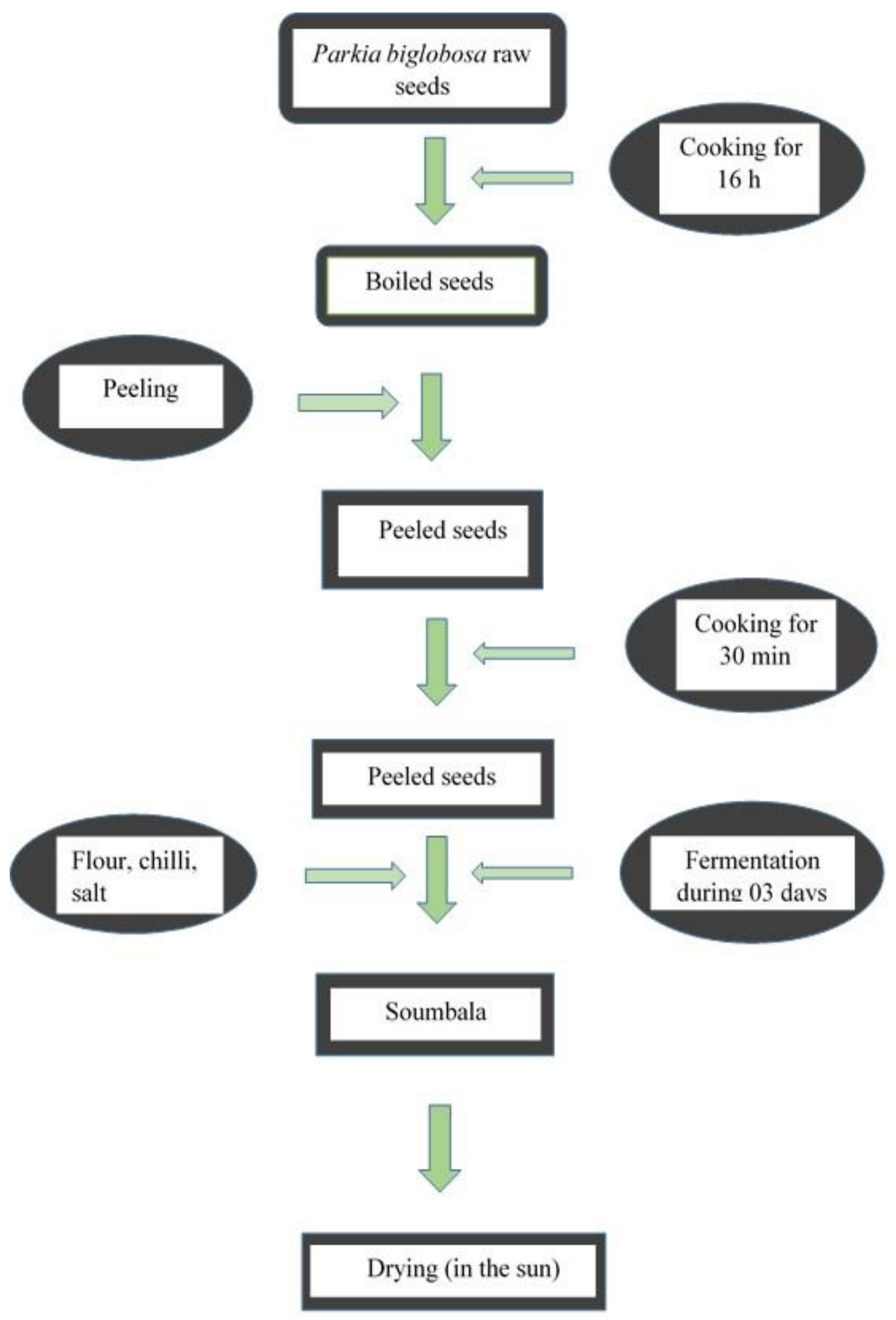

Figure 2: «Gouin » community’s « soumbala » production diagram. 


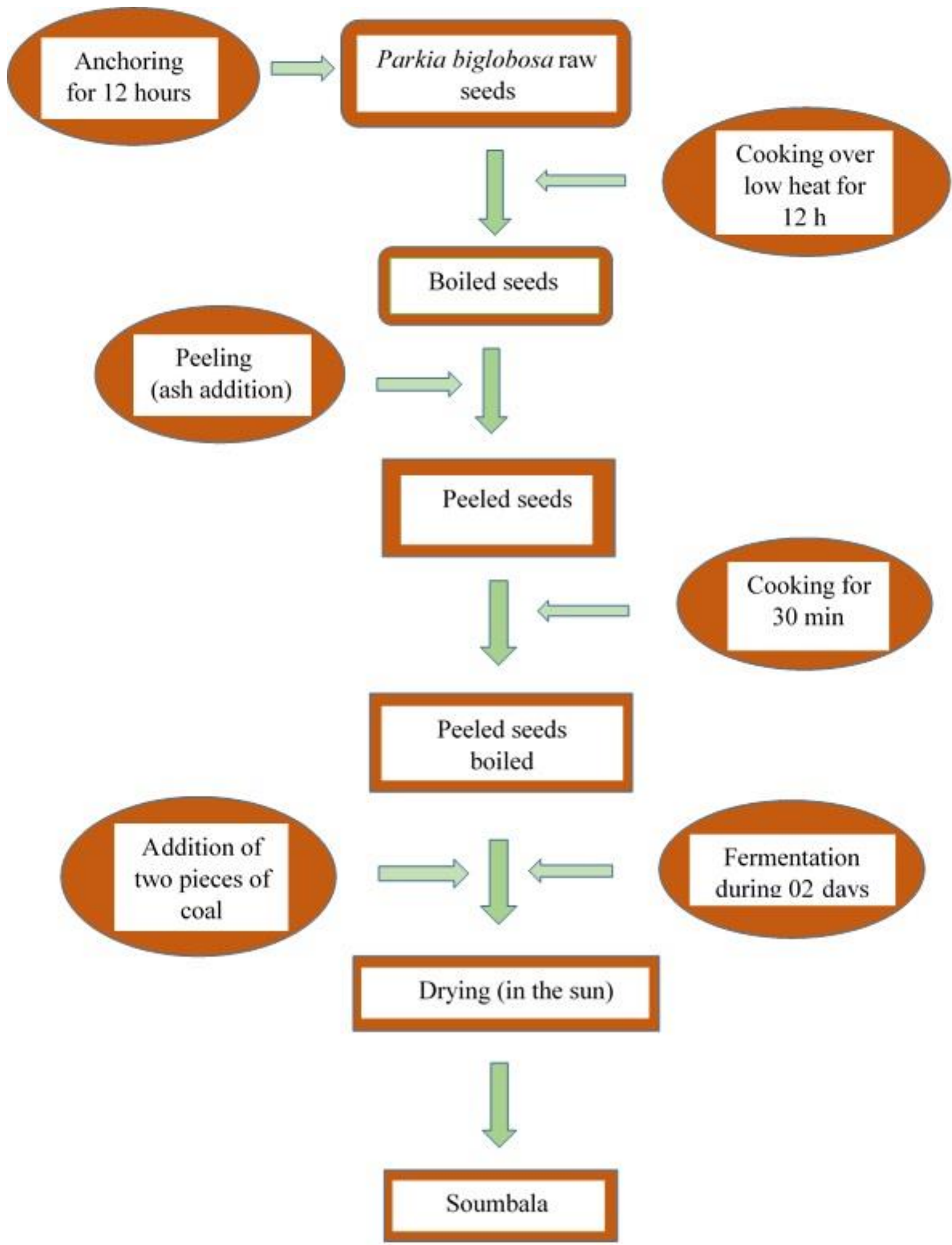

Figure 3: « Moose » community's « soumbala » production diagram. 


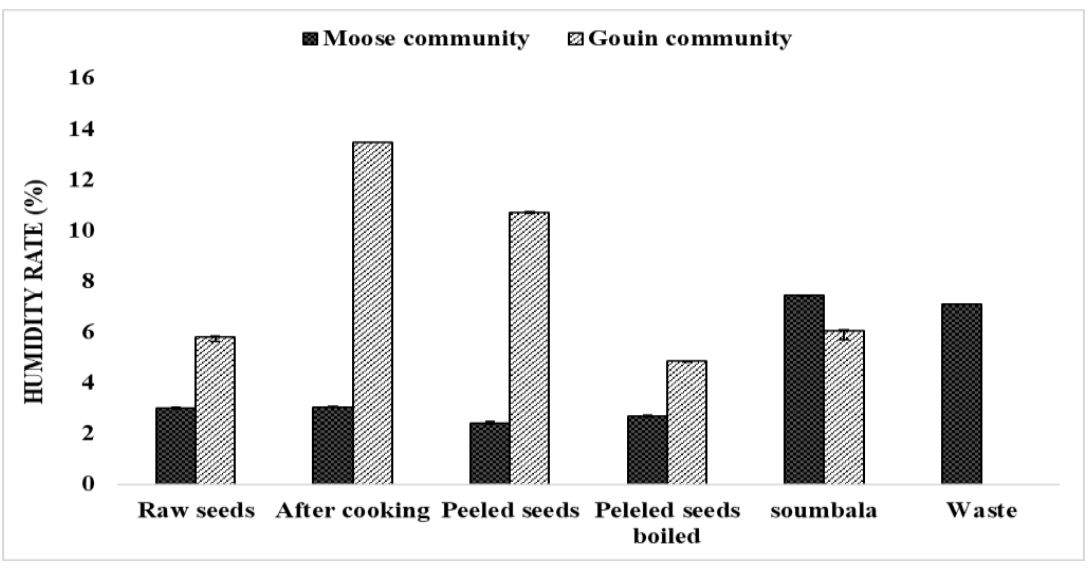

Figure 4: Humidity rate at each step of «soumbala» manufacturing process in « Gouin » and «Moose » communities. Results are expressed in percentages.

Table 1: Results for ash content determination. Results are expressed in percentages.

\begin{tabular}{|c|c|c|c|c|c|}
\hline & $\begin{array}{l}\text { Raw seeds* } \\
(\%)\end{array}$ & $\begin{array}{l}\text { After cooking } \\
(\%)\end{array}$ & $\begin{array}{l}\text { Peelded seeds } \\
(\%)\end{array}$ & $\begin{array}{l}\text { Peeled seeds } \\
\text { boiled }(\%)\end{array}$ & $\begin{array}{l}\text { «Soumbala » } \\
(\%)\end{array}$ \\
\hline $\begin{array}{l}\text { «Gouin » } \\
\text { community }\end{array}$ & $9.67 \pm 0.01$ & $9.93 \pm 5.24$ & $5.75 \pm 0.09$ & $7.23 \pm 0.01$ & $4.58 \pm 0.08$ \\
\hline $\begin{array}{l}\text { «Moose » } \\
\text { community }\end{array}$ & $4.15 \pm 0.09$ & $2.93 \pm 0.15$ & $1.87 \pm 0.03$ & $2.05 \pm 0.01$ & $2.03 \pm 0.01$ \\
\hline
\end{tabular}

Table 2: Results of $\mathrm{pH}$ measurements.

\begin{tabular}{|c|c|c|c|c|c|}
\hline & Raw seeds* & $\begin{array}{l}\text { After } \\
\text { cooking }\end{array}$ & Peeled seeds & $\begin{array}{ll}\begin{array}{l}\text { Peeled } \\
\text { boiled }\end{array} & \text { seeds } \\
\end{array}$ & « soumbala » \\
\hline $\begin{array}{l}\text { «Gouin » } \\
\text { Community }\end{array}$ & $4.63 \pm 0.00$ & $4.81 \pm 0.03$ & $5.26 \pm 0.04$ & $6.10 \pm 0.03$ & $6.03 \pm 0.03$ \\
\hline $\begin{array}{l}\text { «Mosse » } \\
\text { community }\end{array}$ & $4.77 \pm 0.01$ & $4.96 \pm 0.06$ & $5.52 \pm 0.07$ & $5.39 \pm 0.01$ & $6.53 \pm 0.05$ \\
\hline
\end{tabular}

Table 3: Results for mineral elements assay. Results are expressed in mg per $100 \mathrm{~g}$ of dry matter of « soumbala ».

\begin{tabular}{|c|c|c|c|c|c|c|}
\hline & \multicolumn{3}{|c|}{ «Gouin » community } & \multicolumn{3}{|c|}{ « Moose » community } \\
\hline & $\begin{array}{l}\text { Iron } \\
(\mathrm{mg} / 100 \mathrm{~g})\end{array}$ & $\begin{array}{l}\text { Zinc } \\
(\mathrm{mg} / 100 \mathrm{~g})\end{array}$ & $\begin{array}{l}\text { Selenium } \\
(\mathrm{mg} / 100 \mathrm{~g})\end{array}$ & $\begin{array}{l}\text { Iron } \\
(\mathrm{mg} / 100 \mathrm{~g})\end{array}$ & $\begin{array}{l}\text { Zinc } \\
(\mathrm{mg} / 100 \mathrm{~g})\end{array}$ & $\begin{array}{l}\text { Selenium } \\
(\mathrm{mg} / 100 \mathrm{~g})\end{array}$ \\
\hline Raw seeds* & $0.07 \pm 0.01$ & $0.02 \pm 0.00$ & $0.03 \pm 0.03$ & $0.04 \pm 0.00$ & $0.04 \pm 0.00$ & $0.02 \pm 0.03$ \\
\hline After cooking & $0.10 \pm 0.03$ & $0.03 \pm 0.02$ & $0.03 \pm 0.04$ & $0.06 \pm 0.01$ & $0.05 \pm 0.02$ & $0.02 \pm 0.06$ \\
\hline Peeled seeds & $0.04 \pm 0.02$ & $0.02 \pm 0.01$ & $0.03 \pm 0.00$ & $0.09 \pm 0.02$ & $0.09 \pm 0.00$ & $0.02 \pm 0.03$ \\
\hline $\begin{array}{l}\text { Peeled boiled } \\
\text { seeds }\end{array}$ & $0.05 \pm 0.00$ & $0.01 \pm 0.03$ & $0.03 \pm 0.01$ & $0.06 \pm 0.00$ & $0.08 \pm 0.00$ & $0.02 \pm 0.01$ \\
\hline «Soumbala » & $0.04 \pm 0.02$ & $0.01 \pm 0.02$ & $0.03 \pm 0.01$ & $0.05 \pm 0.00$ & $0.09 \pm 0.01$ & $0.03 \pm 0.00$ \\
\hline Waste & NA & NA & NA & NA & NA & NA \\
\hline
\end{tabular}




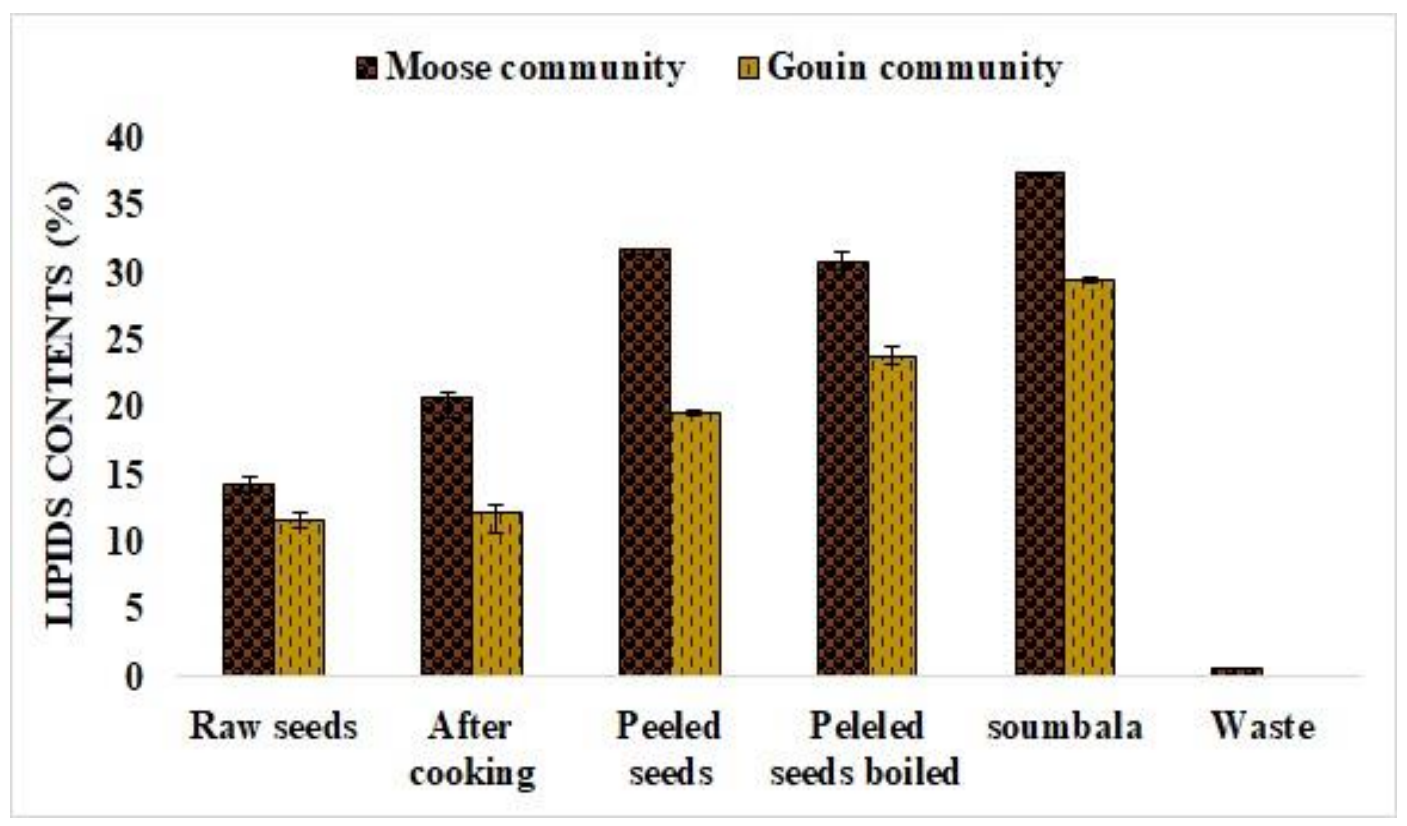

Figure 5: Lipids contents at each step of «soumbala » manufacturing process in «Gouin » and «Moose » communities. Results are expressed in percentages.

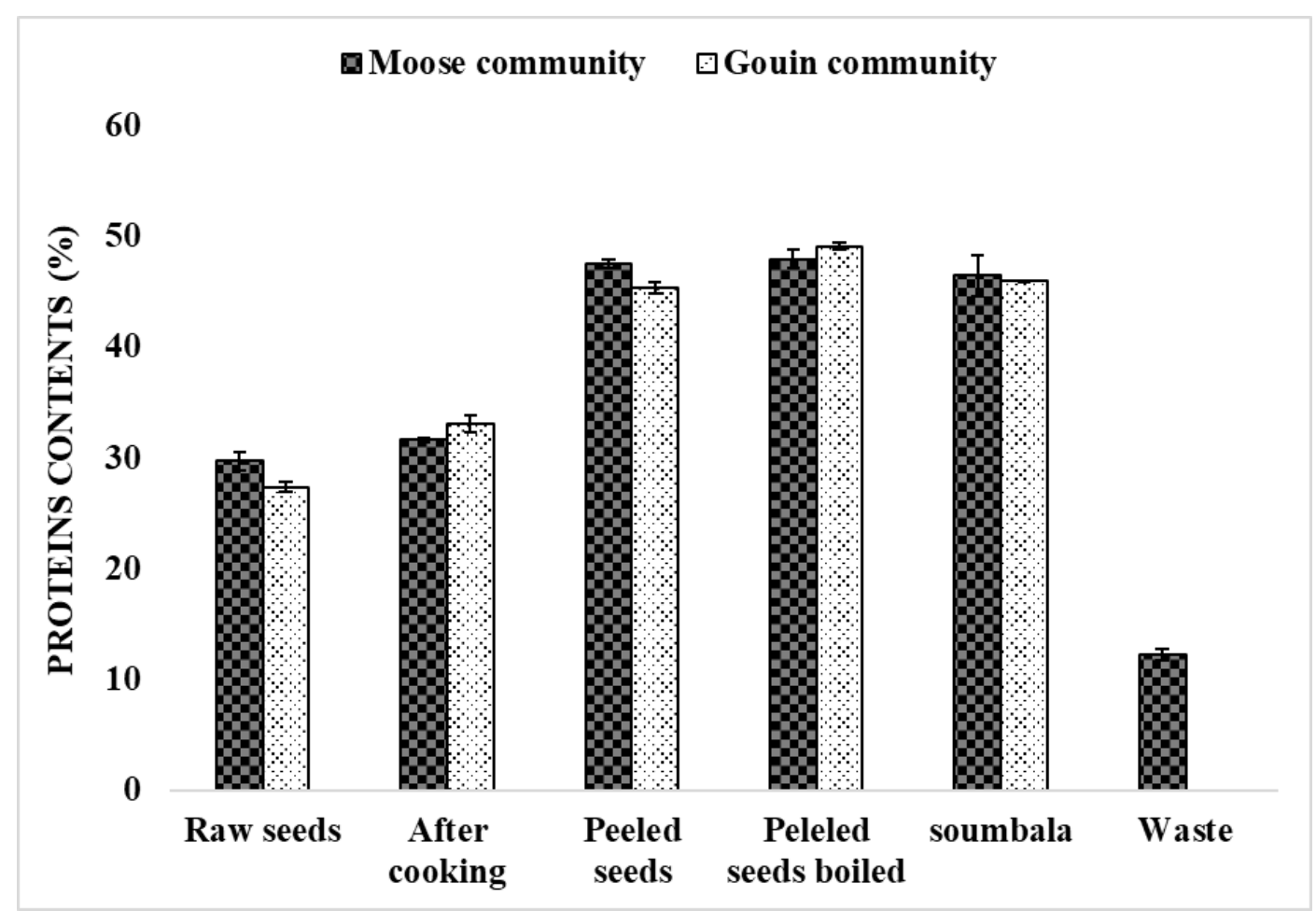

Figure 6: Proteins contents at each step of «soumbala» manufacturing process in «Gouin » and « Moose » communities. Results are expressed in percentages. 
Table 4: Results for protein fractions (albumins, globulins, prolamins, glutellins) contents. Results are expressed in equivalent grams of BSA per 100 grams (gBSA/100g) of protein.

\begin{tabular}{|c|c|c|c|c|c|c|c|c|}
\hline & \multicolumn{4}{|c|}{ « Gouin » community } & \multicolumn{4}{|c|}{ «Moose » community } \\
\hline & Albumin & Globulin & Prolamin & Glutelin & Albumin & Globulin & Prolamin & Glutelin \\
\hline Raw seeds* & $5.27 \pm 0.45$ & 0 & $2.80 \pm 2.68$ & $14.21 \pm 1.24$ & $13.51 \pm 0.42$ & $1.17 \pm 0.28$ & $2.89 \pm 0.54$ & $14.49 \pm 0.23$ \\
\hline After cooking & $3.20 \pm 0.52$ & $0.39 \pm 0.95$ & $1.73 \pm 0.68$ & $11.30 \pm 0.27$ & $1.38 \pm 0.34$ & $0.32 \pm 0.56$ & 0 & $11.10 \pm 0.55$ \\
\hline Peeled seeds & $2.08 \pm 0.35$ & 0 & $0.60 \pm 1.21$ & $6.69 \pm 0.93$ & $0.26 \pm 0.12$ & $0.41 \pm 0.63$ & 0 & $1.45 \pm 0.88$ \\
\hline $\begin{array}{l}\text { Peeled boiled } \\
\text { seeds }\end{array}$ & $0.61 \pm 0.26$ & $0.75 \pm 0.31$ & 0 & $2.01 \pm 0.60$ & $0.67 \pm 0.04$ & 0 & 0 & $2.14 \pm 0.11$ \\
\hline «Soumbala » & $0.76 \pm 0.17$ & $1.09 \pm 0.62$ & 0 & $22.76 \pm 1.24$ & $1.65 \pm 0.35$ & $0.59 \pm 0.48$ & 0 & $17.88 \pm 1.05$ \\
\hline Waste & NA & NA & NA & NA & $10.05 \pm 0.52$ & $0.88 \pm 0.33$ & 0 & 0 \\
\hline
\end{tabular}

Table 5: Results for carbohydrates content determination. Results are expressed in percentages.

\begin{tabular}{|c|c|c|c|c|c|}
\hline & $\begin{array}{l}\text { Raw seeds* } \\
(\%)\end{array}$ & $\begin{array}{l}\text { After } \\
\text { cooking (\%) }\end{array}$ & $\begin{array}{l}\text { Peeled seeds } \\
(\%)\end{array}$ & $\begin{array}{l}\text { Peeled seeds } \\
\text { boiled }(\%)\end{array}$ & $\begin{array}{l}\text { «Soumbala » } \\
(\%)\end{array}$ \\
\hline $\begin{array}{l}\text { «Gouin » } \\
\text { community }\end{array}$ & $45.34 \pm 0.03$ & $31.36 \pm 0.08$ & $18.41 \pm 0.00$ & $9.09 \pm 0.07$ & $18.46 \pm 0.05$ \\
\hline $\begin{array}{l}\text { «Moose » } \\
\text { community }\end{array}$ & $48.84 \pm 0.01$ & $44.68 \pm 0.04$ & $15.43 \pm 0.02$ & $16.46 \pm 0.02$ & $6.66 \pm 0.08$ \\
\hline
\end{tabular}

\section{DISCUSSION}

«Soumbala » is a condiment highly prized by West African people. It is used to flavour several types of dishes. In Benin and Burkina Faso, in addition to their being used to enhance the food taste, the seeds are thought to be suitable for complementary formulations against infant malnutrition, especially as a source of protein and non-heme iron (Chadare et al., 2018). Several parameters related to the nutritional and hygienic quality of « soumbala » were identified by this study.
The « soumbala » mean humidity rate ranged from $2.03 \% \pm 0.01$ to $4.58 \% \pm 0.08 \%$. These values were lower than those reported by Camara et al. (2016) which values ranged from $15.35 \% \pm 3.28$ to $27.53 \% \pm 2.33$. This difference could be explained by the fermentation process. Camara et al. (2016) used spontaneous fermentation in their study, which involved, not only several strains of Bacillus but also other microorganisms such as Staphylococci. Results reported by Ibrahim et al. (2011a) indicated that the increase in 
humidity rate during fermentation could be due to an increase in the fermentative activity of the microorganisms releasing water molecules. The two communities' humidity rates were different and this difference was statistically significant. The high humidity rate of samples taken in the "Moose » community may be connected to the drying time that is shorter than that of samples taken in « Gouin » community. Also the «néré » seeds used by the « Moose » female producers could have a better capacity of water absorption and retention, compared to those used by the « Gouin» femal producers. High humidity rate in « soumbala » could promote the proliferation of microorganisms within the seed, which could accelerate its deterioration during storage (Popoola et al., 2007).

The ash contents were higher at all the « soumbala » production stages in the «Gouin» community. The difference from the «Moose » samples was statistically significant and is believed to be due to the diversity of fermentation processes. Indeed, for fermentation, the seeds were covered by the " Gouin » community with corn flour, chili pepper, salt, and two pieces of coal, whereas the seeds were covered by the "Moose » community with only two pieces of coal.

The $\mathrm{pH}$ determination showed a gradual increase in $\mathrm{pH}$ values during the «soumbala » manufacturing process in both the «Gouin » and «Moose » communities. This gradual increase in $\mathrm{pH}$ values is thought to be due to the continuous microbial degradation of seed proteins into peptide, amino acids and ammonia (Okpara et al., 2017). The pH of samples from « Moose » community is slightly higher than that of samples from «Gouin » community but the differences were not statistically significant. However, this difference could be due to the "Moose » community samples protein contents, which is slightly higher than that of the "Gouin » community samples. Indeed, there is a relationship between the protein level and the $\mathrm{pH}$ (Ibrahim et al., 2011a). The increase in $\mathrm{pH}$ could be due to a proteins degradation into ammonia (Sarkar et al., 2002). In fact, the higher the level of protein is, the higher the level of ammonia will be and the higher the $\mathrm{pH}$ values.

The mineral elements contents slightly varied during the « soumbala» manufacturing process in the two communities of «Gouin » and «Moose». For selenium, the content remained constant at all stages of the manufacturing process. It is therefore reasonable to believe that the manufacturing process would not significantly influence the mineral element content of « soumbala ». However, there were some variations in the mineral element contents of the «Gouin » and « Moose » samples. Even though these variations were not statistically significant, they could be related to the nature, $\mathrm{pH}$ and soils, on which the «néré » seeds were collected, mineral elements composition. Thus, Olatunji et al. (2017), showed in their study that the mineral composition of plant fruits in general and okra in particular was a function of the soils mineral elements composition. Indeed, plants draw mineral elements from the soil and air for metabolic needs including the process of photosynthesis, lignin synthesis, germination and pollen fertility (Hopkins et al., 2003).

The total lipid levels gradually increased along the « soumbala » manufacturing process in both «Gouin » and « Moose » communities. This increase in lipid levels would be the result of the concentration of lipids by the treatments applied at each stage of the "soumbala » manufacturing process. The lipid levels in samples, taken from the « Gouin » community differed significantly from those in samples taken from the «Moose » community. This could be due to the origin of the seeds used to make « soumbala ». Indeed, the more fertile and watered the soil on which the seedlings are planted, the greater the reserves stored in the seed in the form of lipids and proteins (Marlos et al., 2008). However, the Western region of Burkina Faso where the « Gouin » community lives is better watered and the soils are more fertile than the regions where the "Moose » community lives. One might therefore think that the «néré » seeds used by the «Moose » 
female producers to make «soumbala » would not come from their regions of residence but from the regions of the country with more water and rich soils.

As for proteins, their levels were constant until the cooking stage. From the peeled seed stage, there was an increase in the protein contents, which remained constant for the next « soumbala » manufacturing stages. It can therefore be said that the seed husks of «néré » would be low in protein. The elimination of these envelopes would then generate a concentration of protein in the peeled seeds. No statistically significant difference was observed between the protein contents of the samples from the two communities «Gouin » and « Moose».

For the protein fractions, albumins and globulins, gradually decreased during the « soumbala » manufacturing process. This decrease would be explained by cooking at high temperature and alkaline fermentation of the «néré » seeds. Indeed, the degradation of albumin is a function of temperature and fermentation. Thus the work conducted by Salma et al. (2017) on pea proteins showed that cooking degrades the native structure of the protein. Similarly, Amier et al. (2016) found a $100 \%$ degradation of wheat proteins after cooking. Indeed, albumin is degraded to ammonia during fermentation (Amier et al., 2016). For glutelins, their level decreases from the raw seeds until after the "peeled seeds cooking » step. This could be explained by the degradation of this protein fraction by the heat experienced by seeds during cooking. The increase in gluteline levels observed in the end product (« soumbala ») in the "Gouin » community would be due to the addition of corn flour during the fermentation step. Indeed, Sawadogo et al. (2020) have shown that cereal flours contain high levels of proteins ranging from $11.7 \%$ to $17.49 \%$. The same increase in glutelin levels in «soumbala » was observed in « Moose » community who did not add cornmeal to boiled peeled seeds during fermentation. Thus, contamination of the boiled peeled seeds during the fermentation process by compounds containing glutelin could be expected. Differences between protein fractions contents in the two communities «Gouin » and « Moose » were not statistically significant.

For carbohydrates, low levels of carbohydrates were found in «soumbala » in both «Gouin » and « Moose » communities compared to other stages of « soumbala » production. This would be due to the microorganisms responsible for the fermentation leading to «soumbala ». These microorganisms draw their energy from the metabolism of carbohydrates leading to their degradation. Indeed, the fermenting microorganisms cause the carbohydrates glycolysis. This allows microorganisms to obtain ATP which is a source of energy for their growth (Ibrahim et al., 2018b). A slight increase in the carbohydrates content is observed in «Gouin » community during the passage from peeled boiled seeds to « soumbala » but this difference with value observed in " Moose » community was not statistically significant. However, this could be explained by the addition of maize flour, which is rich in carbohydrates during fermentation. Indeed, according to (Sagbo et al., 2017), maize has an important carbohydrates fraction.

\section{Conclusion}

The aim of this work was to contribute to the determination of « soumbala » manufacturing processes influence on its nutritional properties. To achieve this goal, biochemical and toxicological analyses were carried out in two different communities: " Gouin » and « Moose». The results obtained showed that: for mineral parameters, variations in grades along the manufacturing process were low in both communities. For selenium, the grades even seemed constant at all stages; for the biochemical parameters, the « soumbala » manufacturing process resulted in a lipids and proteins concentration.

In terms of protein fractions, albumin and globulin levels decreased during the « soumbala » manufacturing process in both communities. Glutelins, on the other hand, increased in the end product (« soumbala»), 
probably due to the addition of corn flour during the fermentation stage. Toxicological analyses for aflatoxin assay did not reveal any contamination for this parameter.

This study showed that the «soumbala » nutritional quality could be affected by manufacturing procedures. It is therefore imperative that approved standard protocols be adopted to maintain the nutritional quality of « soumbala » wherever it is produced.

\section{COMPETING INTERESTS}

The authors declare that they have no competing interests what so ever.

\section{AUTHORS' CONTRIBUTIONS}

EK was involved in proposal development, data collection, data analysis and review of the manuscript and overall supervision of the work. MB and RK were involved in title identification, proposal development, manuscript preparation, data interpretation and laboratory data supervision. TS was involved in laboratory testing, data and sample collection. RB was associated to data acquisition, data interpretation and review of manuscript. FN and JS were involved in data interpretation and review of manuscript.

\section{ACKNOWLEDGEMENTS}

We thank the study participants for their willingness to offer information and provide samples. We are indebted to the laboratory technologists who helped us.

\section{REFERENCES}

Ahouansou RH. 2012. Contribution to the development and optimization of food processing equipment in Benin: Case of the « néré » husker and the afitin press. $\mathrm{PhD}$ Thesis, University of AbomeyCalavi, Calavi, 285 p.

Akanda F, Parkouda C, Suurbaar J, Donkor AM, Owusu-Kwarteng J. 2018. Effects of mechanical dehulling on microbiological characteristics and chemical changes during processing of Parkia biglobosa seeds into dawadawa, a West African alkaline fermented condiment. Journal of the Ghana Science Association, 17: 1319.

Alabi DA, Akinsulire OR, Sanyaolu M. 2005. Qualitative determination of chemical and nutritional composition of Parka biglobosa (Jacp.) Benth. African Journal of Biotechnology, 4: 812-815.

Amier L. 2016. Electrophoretic profile of a traditionally fermented durum wheat type Hamoum BFH compared to normal durum wheat. Master's degree Thesis, Abdelhamid Ibn Badis-Mostaganem University, Oran, $61 \mathrm{p}$.

AOAC 185.15. 1990. Determination of lipid in meat and poultry products. In Official methods of analysis of the Association of Official Analytical Chemists, Cunnif P $\left(15^{\text {th }}\right.$ ed). Arlington: Washington DC, USA.

AOAC 920.153. 1997. Ash of meat. In Official methods of analysis of the Association of Official Analytical Chemists, Cunnif P ( $16^{\text {th }}$ ed.). Arlington: Washington DC, USA.

AOAC 950.46. 1997. Humidity rate in meat. In Official methods of analysis of the Association of Official Analytical Chemists, Cunnif P $\left(16^{\text {th }}\right.$ ed $)$. Arlington: Washington DC, USA.

AOAC 979.09. 1999. Determination of protein in flour. In. Official Method of Analysis of the Association of Official Analytical Chemists, Champain P $\left(17^{\text {th }}\right.$ ed). Arlington: Washington DC, USA.

Bradford MM. 1976. Protein fractions extraction method. Analytical Biochemisry, 72: 248-254.

Burlando B, Palmero S, Cornara L. 2019. Nutritional and medicinal properties of underexploited legume trees from West Africa. Critical Reviews in Food Science and Nutrition, 59: 178-188. DOI: https://doi.org/10.1080/10408398.2018.1 551776

Camara F, Soro S, Traore S, Brou K, Dje KM. 2016. Biochemical and microbiological characteristics of African mustards produced from fermented seeds of Parkia biglobosa and Glycine max, sold in Côte d'Ivoire. International Journal of Biology 
and Chemical Sciences, 10(2): 506-518.

DOI: https://doi.org/10.4314/ijbcs.v1 $0 \mathrm{i} 2.5$

Campbell-Platt G. 2010. African locust bean (Parkia species) and its West African Fermented Food Product, Dawadawa. Ecology and Food Nutrition, 9: 123-132. DOI:https://doi.org/10.1080/03670244.1 980.9990590

Chadare JF, Madode YE, Fanou-Fogny N, Kindossi JM, Ayosso JOG, Honfo HS, Kayodé APP, Liennemann AR, Hounhouigan DJ. 2018. Indigenous food ingredients for complementary food formulations to combat infant malnutrition in Benin: A review. Journal of the Science of Food and Agriculture, 98: 439-455. DOI: https://doi.org/10.1002/jsfa.8568

Dabiré Y, Mogmenga I, Somda MK, Ugwuanyi JO, Ezeogu LI, Dicko HM, Traoré AS. 2020. Production technique, safety and quality of « soumbala », a local food condiment sold and consumed in Burkina Faso. African Journal of Food, 14: 38-52. DOI: https://doi.org/10.5897/AJFS2019.1891

Demirel S, Tuzen M, Saracoglu S, Soylak M. 2008. Evaluation of various digestion procedure for trace element contents of food materials. Journal of Hazardous Materials, 152: 1020-1026. DOI: https://doi.org/10.1016/j.jhazmat.2007.0 7.077

Diawara B, Sawadogo L, Amoa-awua WK, Jakobsen M. 1998. Quality system for the production of « soumbala ». Plant Foods for Human Nutrittion, 38: 224-230.

Hopkins GW, Evrard CM, Rambour S. 2003. Physiologie végétale. De Boeck: Brussels.

Ibrahim AD, Sani A, Shinkafi SA. 2011a. Production, microbiological and physicochemical evaluation of «dawadawan botso » (a condiment) produed by the fermentation of Hibiscus sabdarifa seeds. International Journal of Biological and Chemistry Sciences, 5: 2481-2490. DOI: http://dx.doi.org/10.4314/ijbcs.v5i6.26
Ibrahim AD, Dandare SU, Mukhtar SI, Adamu SA, Jumare FI, Sa'adatu A, Shinkafi SA. 2018b. Towards an efficient starter culture to produce dawadawa botso : a traditional condiment produced by fermentation of Hibiscus sabdariffa seeds. International Journal of Biological and Chemical Sciences, 12(2): 636-649. DOI:https://dx.doi.org/10.4314/ijbcs.v12 i2.2

Marlos AB, Claudivan FL, Enéas GF, Carlos EBA, José TP. 2008. Physiology of cashew plants grown under adverse conditions. Brazilian Journal of Plant Physiology, 19: 449-461. DOI: https://doi.org/10.1590/S167704202007000400012

Musaiger AO, Al-Saad JA, Al-Hooti DS, Khunji ZA. 1998. Chemical composition of fermented dairy products consumed in Bahrain. Food Chemistry, 61: 49-52. DOI: https://doi.org/10.1016/S03088146(97)00129-5

Okpara AN, Ugwuanyi JO. 2017. Evolving status of African food seasoning agents produced by fermentation. Soft Chemistry and Food Fermentation, 17: 465-505. DOI: https://doi.org/10.1016/B978-0-12811412-4.00015-1

Olatunji OA, Oke SO, Isola EF, Akinyemi DS, Omodara AA. 2015. Relationship between the standing vegetation, soil properties and soil seed bank of an industrially degraded vegetation of Iron Smelting Factory. International Journal of Biological and Chemical Sciences, 9(2): $\quad 614-632 . \quad$ DOI: http://dx.doi.org/10.4314/ijbcs.v9i2.4

Ouoba LI. 2017. Traditional alkaline fermented foods: Selection of functional Bacillus starter cultures for «soumbala» production. In Starter cultures in food production, Speranza B, Bevilacqua A, Corbo MR, Sinigaglia M ( $1^{\text {st }}$ Ed). John Wiley \& Sons: New Jersey - USA; 8: 370383.

DOI: https://doi.org/10.1002/9781118933794. $\operatorname{ch} 18$ 
Popoola TO, Kolapo AL, Afolabi OR. 2007. Biochemical deterioration of soybean dawa dawa, a condiment. Journal of Food, Agriculture and Environment, 1: 67-70.

Ragab DM, Babiker EE, Eltinay AH. 2004. Fractionation, solubility and functional properties of cowpea (Vigna unguiculata) protein us affected by $\mathrm{pH}$ and/or salt concentration. Food Chemistry, 84: 207212. DOI: https://doi.org/10.1016/S03088146(03)00203-6

Sagbo FSY, Aïssi MV, Hounkpatin WA, Houedo C, Dansi A, Soumanou MM. 2017. Physicochemical and pasting properties of some local and improved maize varieties cultivated in Benin. International Journal of Biological and Chemical Sciences, 11(4): 1753-1765. DOI:

http://dx.doi.org/10.4314/ijbcs.v11i4.27

Salma BH. 2017. Formulating microbial consortia to control the sensory properties of pea protein-based gels. PhD thesis, University of Paris-Saclay, Paris, 228 p.

Sarkar PK, Hasenack B, Nout MJR. 2002. Diversity and functionality of Bacillus and related genera isolated from spontaneously fermented soybeans
(Indian Kinema) and locust beans (African Soumbala). International Journal of Food Microbiology, 77: 175186.

Sawadogo N, Naoura G, Ouedraogo MH, Tonde M, Tiendrebeogo J, Tiendrebeogo KF, Bougma LA, Tiama D, Zongo JD. 2020. Phenotypic variability and correlation estimates for traits of burkina faso' sweet grain sorghum genotypes. African Crop Science Journal, 28 : 517 527.

DOI : https://dx.doi.org/10.4314/acsj.v28i4.3

Sereme A, Millogo-Rasolodimby J, Guinko S, Nacron M. 2008. Therapeutic properties of tannin plants from Burkina Faso. Pharmacopoeia and Traditional African Medicine, 15: 41-49.

Tokuba JM. 2012. Phytochimie et propriétés anti hypertensives de deux plantes utilisées dans le traitement traditionnel de l'hypertension artétérielle au Bénin : Parkia biglobosa (Jacq.) Benth. (Mimosaceae) and Spondias mombin L. (Anarcadiaceae). PhD Thesis, University of Abomey-Calavi, Calavi, 234 p. 